\title{
ゲルマニウム陰イオンの化学一最近の進歩一
}

持 田 邦 夫*

\section{Recent Progress in the Chemistry of Germyl Anions}

Kunio MOCHID*

Syntheses, structures, and some reactions of organometallic compounds having germanium-metal bond have been reviewed forcusing on advances in 1980's.

Key words : Germyl anions ; Alkali metals ; Synthesis ; Structure ; Reactivity.

\section{1. はじめに}

14 族元素の中でゲルマニウム化合物が注目をあつめ ている。その範囲は有機金属化学, 反応機構の解明, 有 機合成試剂など基礎的な分野から，新薬や新素材の開発 など応用面にまでおよぶ。ゲルマニウム化合物は高価で 入手困難であるという先入観から充分な研究なくしてと もすればその化学は炭素, ケイ素, スズ化合物の化学と 多かれ少なかれ類似していると説明されてきた。しかし ながら,ゲルマニウム化合物に関する著者らの研究結果 およびその他の最近の報告から，ケイ素とゲルマニウム， ゲルマニウムとスズの元素間には従来考えられていた以 上に反応性や構造などの差がしばしば見い出され，ゲル マニウム化合物の研究なくしては 14 族元素化合物を解 釈する上で困難に直面する。1 14 族元素不安定化合物の 一つである陰イオン化合物の場合も同様である。

炭素陰イオン(カルバニオン)やケイ素陰イオンは有機 化学や有機金属化学において重要な化学種であり,これ らに関する総説は多い(1 3)。しかし，ゲルマニウム陰イ オンに関する総説はなく, ケイ素陰イオンやスズ陰イオ ンの関連種として議論されているにすぎない4)。ここで はゲルマニウム陰イオンに関する最近の研究を他の 14 族元素イオンと比較しながら, 合成法, 構造, および反 応性などを中心に概観する。なお，1980 年以前のゲル

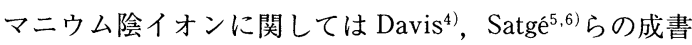

* 学習院大学理学部化学科

* Department of Chemistry, Faculty of Science, Gaku shuin University

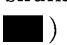

の一部に整理されているので参考にして欲しい。

\section{2. 合成法}

フェニル基を一つ以上有するゲルマニウム金属は次の ようにGilmanの方法によってエーテル系溶媒やアミン 系溶媒中で合成することができ，その化学は比較的よく 研究されている4)。

$$
\begin{aligned}
& 2 \mathrm{PhR}_{2} \mathrm{GeCl} \stackrel{2 \mathrm{M}}{\longrightarrow} \mathrm{PhR}_{2} \mathrm{GeGeR}_{2} \mathrm{Ph} \\
& \stackrel{2 \mathrm{M}}{\longrightarrow} 2 \mathrm{PhR}_{2} \mathrm{GeM} \\
& (\mathrm{R}=\text { フェニルまたはアルキル基; } \mathrm{M}=\mathrm{Na}, \mathrm{Li}, \mathrm{K})
\end{aligned}
$$

トリアルキル置換ゲルマニウム金属, $\mathrm{R}_{3} \mathrm{GeM}(\mathrm{R}=\boldsymbol{P}$ ルキル, $\mathrm{M}=\mathrm{Li}, \mathrm{Na}, \mathrm{K})$ の合成には上の方法は適当では ない。

$$
\begin{aligned}
&\left(\mathrm{R}_{3} \mathrm{Ge}\right)_{\mathrm{n}} \mathrm{M}^{\prime}+\mathrm{nLi} \stackrel{\mathrm{THF} \text { または }}{\underset{\text { ヘキサン }}{\longrightarrow}} \mathrm{nR}_{3} \mathrm{GeLi}+\mathrm{M}^{\prime} \\
&\left(\mathrm{M}^{\prime}=\mathrm{Hg}, \mathrm{Cd} ; \mathrm{n}=2, \mathrm{M}^{\prime}=\mathrm{Tl} ; \mathrm{n}=3\right)
\end{aligned}
$$

$$
\begin{aligned}
\mathrm{R}_{3} \mathrm{GeGeR}_{3}+2 \mathrm{M} \stackrel{\text { HMPA }}{\longrightarrow} & 2 \mathrm{R}_{3} \mathrm{GeM} \\
& (\mathrm{R}=\mathrm{Me}, \mathrm{Et}, \mathrm{Pr}, \mathrm{Bu})
\end{aligned}
$$

反応 (式 2)はテトラヒドロフラン (THF)やへキサン中で 行われる金属一金属交換反応があるが，ゲルマニウム水 銀やカドミウムを必要とすること，および反応収率が低 い難点がある7)。反応(式 3)はへキサメチルホスホル アミド(HMPA)中で極めて円滑に定量的に進行する8)。 
この反応はエチルアミンなどアミン系溶媒でも進行する が, 反応時間は長くなる。

ジゲルマンに適当な求核剂を作用させてもゲルマニウ 么金属を合成できる ${ }^{9)}$ 。しかし, 反応(式 3 )に比較し, ジゲルマンの半分しかゲルマニウム金属の生成に利用で きない不利な点がある。

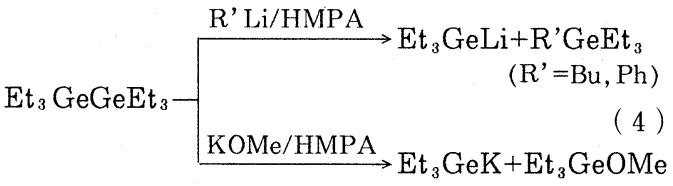

反応 $($ 式 4,5)は HMPA 中でのみ進行する。

最近注目を浴びているクラウンエーテルもまた，陽イ オンを取り込んで陰イオンを活性化することが知られて いるが，これを用いても同様に反応(式 5)をひき起こす ことができる。この場合には THF やベンゼンなどの溶 媒を用いることができる(10)。

$$
\begin{array}{r}
\mathrm{Me}_{3} \mathrm{GeGeMe}_{3}+\mathrm{KOMe} \frac{18-\text { クラウン- } 6}{\mathrm{THF} \text { またはベンゼン }} \\
\mathrm{Me}_{3} \mathrm{GeK}+\mathrm{Me}_{3} \mathrm{GeOMe}
\end{array}
$$

溶媒に HMPA を用いるとクロロゲルマンからもトリ アルキル置換ゲルマニウム金属が合成できる ${ }^{9)} 。$

$$
\begin{aligned}
\mathrm{R}_{3} \mathrm{GeCl}+2 \mathrm{M} \stackrel{\mathrm{HMPA}}{\longrightarrow} \mathrm{R}_{3} \mathrm{GeM}+\mathrm{MCl} \\
\text { ( } \mathrm{R}=\text { アアルキル基) }
\end{aligned}
$$

反応 (式 7)は極めて円滑かつ定量的に進行する。クロロ ゲルマン合成の容易さを考えるとトリアルキル置換ゲル マニウム金属のもっとも簡単な合成法といえる。金属塩 も同時に生じるが，ゲルマニウム金属を用いる反応では 反応に影響をおよぼさないことが知られている

ヒドロゲルマンにアルカリ金属や適当な求核剂を作用 させる方法も容易で収率の良い合成法である5)。

$$
\begin{aligned}
\mathrm{R}_{3} \mathrm{GeH}-\stackrel{2 \mathrm{M}}{\stackrel{\mathrm{R} \mathrm{Li}^{\prime}}{\longrightarrow}} \underset{\mathrm{R}}{\stackrel{\mathrm{ReM}}{\longrightarrow}} \mathrm{R}_{3} \mathrm{GeLi}+\mathrm{R}^{\prime} \mathrm{H}
\end{aligned}
$$

( $\mathrm{R}, \mathrm{R}^{\prime}=$ フェニルまたはアルキル基)

フェニル基を一つ以上有するヒドロゲルマンはエーテル 系溶媒中でも進むのに対し，アルキル置換ヒドロゲルマ ンはHMPA 中でのみ進む。

ジヒドロゲルマンにアルカリ金属を反応させるとゲル ミレン金属を ${ }^{12)}$ ，適量のアルキルリチウムを反応させる と水素化ゲルマニウム金属など興味ある陰イオン種が合
成できる ${ }^{13)}$ 。

$$
\underset{\mathrm{Ar}_{2} \mathrm{GeH}_{2}-\stackrel{4 \mathrm{M}}{\stackrel{\mathrm{BuLi}}{\longrightarrow}} \mathrm{Ar}_{2} \mathrm{GeM}_{2}+2 \mathrm{MH}}{\stackrel{\mathrm{THF}}{\longrightarrow} \mathrm{Ar}_{2}(\mathrm{H}) \mathrm{GeLi}+\mathrm{BuH}}
$$

特異な合成法として, ゲルマノキサン $(\mathrm{Ge}-\mathrm{O}-\mathrm{Ge}$ 結合 を有する一連の化合物)にアルカリ金属を反応させた $\eta^{8)}$ ，クロロゲルマンにマグネシウム金属蒸気やカルシ ウム金属蒸気を反応させる方法がある ${ }^{14)}$ 。後者の反応は 溶媒を必要としない。

$$
\begin{aligned}
& \mathrm{Et}_{3} \mathrm{GeOGeEt}_{3}+2 \mathrm{~K} \stackrel{\mathrm{HMPA}}{\longrightarrow} \mathrm{Et}_{3} \mathrm{GeK}+\mathrm{Et}_{3} \mathrm{GeOK} \\
& \mathrm{Et}_{3} \mathrm{GeCl}+\mathrm{Ca} \text { (蒸気) } \longrightarrow \mathrm{Et}_{3} \mathrm{GeCaCl}
\end{aligned}
$$

\section{3. 構造}

ゲルマニウム金属が関与する反応を理解する重要な要 素の一つに構造的知見がある。しかし，ゲルマニウム金 属は湿気や空気に対し非常に鋭敏で，ただちに対応し水 素化物や酸素化物に分解する。従って, その研究は現在 のところ主としてUVやNMR などの測定手段に限られ ている。

THF や HMPA 中で合成されたゲルマニウム金属は黄 色を呈する。代表的なゲルマニウム金属溶液の UV デー 夕を表 1 に整理する ${ }^{15,16) 。}$

表 1 よりゲルマニウム金属の吸収極大の值におよぼす 対カチオンの性質は $\mathrm{Li} \simeq \mathrm{Na}<\mathrm{K}$ となること, フェニル 置換ゲルマニウム金属の吸収極大の值がアルキル置換の それに比較して大きいことがわかる。観測されたUV 吸 収は，ゲルマニウム金属の不対電子を収容している反結 合性軌道(HOMO) からベンゼン環の $\pi^{*}$ およびゲルマニ ウム-炭素結合の $\sigma^{*}$ (それぞれ LUMO)への遷移として

Table 1 Absorption data of UV spectra of germylalkali metals.

\begin{tabular}{l|c|r|r|c}
\hline \multirow{2}{*}{ Compound } & \multirow{2}{*}{ Solvent } & \multicolumn{3}{|c}{$\lambda$ max $/ \mathrm{nm}$} \\
\cline { 3 - 5 } & & $\mathrm{M}=\mathrm{Li}$ & $\mathrm{Na}$ & $\mathrm{K}$ \\
\hline $\mathrm{Ph}_{3} \mathrm{GeM}$ & $\mathrm{THF}$ & 310 & 300 & 330 \\
$\mathrm{Ph}_{2} \mathrm{MeGeM}$ & $\mathrm{THF}$ & 310 & 315 & 325 \\
$\mathrm{PhMe}_{2} \mathrm{GeM}$ & $\mathrm{THF}$ & 290 & 290 & 305 \\
$\mathrm{Me}_{3} \mathrm{GeM}$ & $\mathrm{HMPA}-\mathrm{THF}$ & 280 & 280 & 300 \\
$\mathrm{Et}_{3} \mathrm{GeM}$ & HMPA-THF & $<280$ & $\simeq 280$ & 290 \\
\hline
\end{tabular}


理解できる。対カチオンの吸収極大におよぼす傾向は, ゲルマニウムー金属結合におけるイオン結合性の寄与が この順に重要になることを意味する。報告されている 14 族元素陰イオンの UV デー夕を比較すると, 吸収極 大は $\mathrm{C}>\mathrm{Si}>\mathrm{Ge} \simeq \mathrm{Sn}$ の順であり，対カチオンの影響は ゲルマニウム金属の場合とほぼ同じである ${ }^{15 \sim 18)}$ 。

ゲルマニウム金属における電子の局在化，非局在化に ついてはNMR の化学シフトで議論できる。フェニル置 換ゲルマニウム金属の ${ }^{1} \mathrm{H},{ }^{13} \mathrm{C}-\mathrm{NMR}$ を対応する中性物 質に比較すると, 両 NMR ともにベンゼン環のメ夕位, パラ位の高磁場シフトが認められる。一方オルト位は低 磁場へシフトをする。電子密度と化学シフトの関係, 立 体的要因の影響の少ないパラ位の化学シフトを解析する ことにより，ゲルマニウム金属におけるベンゼン環上へ の電子の非局在化が認められる。14 族元素陰イオンで は,この非局在化の程度は $\mathrm{C}>\mathrm{Ge}>\mathrm{Si}>\mathrm{Sn}$ となり $\mathrm{np}-2$ $\mathrm{p}$ 共役の有効性とほぼ一致する。ケイ素とゲルマニウム 間の逆転は炭素-ケイ素間 $(1.95 \AA)$ と炭素-ゲルマニウム 間 $(2.00 \AA)$ の結合距離により説明できる。より短かい炭 素-ケイ素結合のためにベンゼン環が歪み, ケイ素上か らベンゼン環への電子の流れがゲルマニウムに比較して 不利になるためであろう。

フェニル置換ゲルマニウム金属の NMR データに比較 して, 対応する炭素陰イオンではベンゼン環のオルト位, パラ位の高磁場シフトとメ夕位の低磁場シフトが認めら れる。これらのことを考えるとフェニル置換ゲルマニウ 厶金属は $\pi$-分極化構造をとり，メ夕位およびパラ位に 電子が局在化しているのに対し, 炭素陰イオンでは電子 は共鳴構造的に流れオルト位およびパラ位に局在化す $ろ^{19 \sim 23)}$ 。

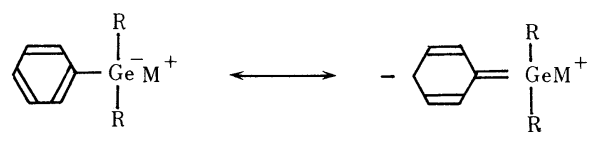

ゲルミルリチウムでのゲルマニウムーリチウム結合に おいて共有結合性がかなり存在することが ${ }^{7} \mathrm{Li}-\mathrm{NMR} に$ より明らかにされている。また 14 族元素ーリチウム間の 会合度は $\mathrm{Pb}<\mathrm{Sn}<\mathrm{Ge} \simeq \mathrm{Si}$ となる。従って共有結合性の 寄与もこの順になる ${ }^{19,22)}$ 。

アルキル置換ゲルマニウム金属の ${ }^{1} \mathrm{H},{ }^{13} \mathrm{C}-\mathrm{NMR}$ を測 定すると対応する中性物質に比較して， $\alpha$ 炭素上のプロ トンの高磁場シフトと, $\alpha$ 炭素の低磁場シフトが認めら れる。同様の現象はアルキル陰イオンでも報告されてい $ろ^{15)}$ 。
ゲルマニウム金属におけるゲルマニウム原子上の大き い陰電荷は, 軌道の再混成を促す。その結果, 不対電子 収容軌道の $\mathrm{s}$ 性が増加し, それに伴ないゲルマニウム炭素間の結合距離の増大となってあらわれる。実際, EXAFS*を用いての研究によるとその程度は約 $10 \%$ 程 度となる ${ }^{24)}$ 。

溶液中でゲルマニウム金属が何量体として存在するか は反応性を理解する上で重要であるが, 充分な研究は行 われていない。最近の X 線回析の結果では, 炭化水素系 溶媒中とエーテル系溶媒中とでは会合度に違いがあるこ とが明らかになっている27)。

\section{4. 化学的性質}

ゲルマニウム金属が関与する諸反応は通常の求核反応 ではあまり見かけないものが多い。この理由として，ゲ ルマニウム金属の求核剤としての作用よりむしろ, 一電 子移動剤としての作用が優先するからであろう。特に, HMPA 中でアルキル置換ゲルマニウム金属にこの傾向 が強い。

化合物の電子供与性の尺度にはイオン化ポテンシャル や電気化学的な酸化電位がある。溶液中でのゲルマニウ ム金属の関与する電子移動反応を理解するため, 酸化電 位が調べられた(表 3 )。ゲルマニウム金属との比較のた め, シリル金属とスズ金属の酸化還元電位も表 3 に整理 した。

Table 2 The distance of germanium-carbon bond of alkyl- and aryl-substituted germylalkali metals and related compounds.

\begin{tabular}{lc}
\hline Compound & $\mathrm{Ge}-\mathrm{C}$ bond $/ \AA$ \\
\hline $\mathrm{Et}_{4} \mathrm{Ge}$ & 1.96 \\
$\mathrm{Et}_{3} \mathrm{GeH}$ & 1.96 \\
$\mathrm{Ph}_{4} \mathrm{Ge}$ & 1.97 \\
$\mathrm{Ph}_{3} \mathrm{GeH}$ & 1.96 \\
$\mathrm{Me}_{3} \mathrm{GeLi}$ & 2.07 \\
$\mathrm{Me}_{3} \mathrm{GeNa}$ & 2.17 \\
$\mathrm{Me}_{3} \mathrm{GeK}$ & 2.10 \\
$\mathrm{Et}_{3} \mathrm{GeLi}$ & 2.06 \\
$\mathrm{Ph}_{3} \mathrm{GeLi}$ & 2.04 \\
\hline
\end{tabular}

* EXAFS (Extended X-ray Absorbance Fine Structure) は X 線の吸収端の近傍数百 $\mathrm{eV}$ の領域に観測される微 細構造のことを指し，それを解析することにより特定 の元素の周りの構造を選択的に知ることができる。ま た固体，液体，気体等どのような相の試料についても 適用でき, 不安定ゲルマニウム化学種の構造研究にも 非常に有用な手段である ${ }^{25.26)}$ 。 
Table 3 Oxidation potentials of group 14 elementcentered anions ${ }^{1)}$.

\begin{tabular}{lc}
\hline Compound & $E_{\mathrm{p}} / \mathrm{V}^{2)}$ \\
\hline $\mathrm{Me}_{3} \mathrm{SiLi}$ & -1.35 \\
$\mathrm{Me}_{3} \mathrm{GeLi}$ & -1.09 \\
$\mathrm{Et}_{3} \mathrm{GeLi}$ & -1.17 \\
$\mathrm{PhMe}_{2} \mathrm{GeLi}$ & -0.98 \\
$\mathrm{Ph}_{2} \mathrm{MeGeLi}$ & -0.62 \\
$\mathrm{Ph}_{3} \mathrm{GeLi}$ & -0.51 \\
$\mathrm{Me}_{3} \mathrm{SnLi}$ & -0.32 \\
\hline
\end{tabular}

1) Determined by $\mathrm{CV}$ at $100 \mathrm{mV} \cdot \mathrm{s}^{-1}$ at a platinum wire electrode in HMPA solution containing the anion (ca. $\left.0.1-0.01 \mathrm{~mol} \mathrm{dm}^{-3}\right)$ and $\mathrm{LiCl}(0.1 \mathrm{~mol}$ $\mathrm{dm}^{-3}$ ) at $25^{\circ} \mathrm{C}$.

2) Half-wave potential $v s$. $\mathrm{SCF}$ in $\mathrm{CH}_{3} \mathrm{CN}$.

電気化学的な酸化電位の值は, 14 族元素陰イオンで は $\mathrm{Si}<\mathrm{Ge}<\mathrm{Sn}$ の順になる。またフェニル基がより多く 置換する程, 酸化電位の值は大きくなる傾向にある。従っ て,ケイ素金属, ゲルマニウム金属は反応する有機基質 （例えば有機ハロゲン化物やカルボニル化合物など）によ り容易に電子を放出する。有機基質の電子受容能力の尺 度-例えば還元電位一に関する研究例は多い29.30)。

ゲルマニウム金属は種々の有機ハロゲン化物と反応し て置換生成物を収率良く与える。

$$
\mathrm{R}_{3} \mathrm{GeM}+\mathrm{R}^{\prime} \mathrm{X} \longrightarrow \mathrm{R}_{3} \mathrm{GeR}^{\prime}+\mathrm{MX}
$$

有機ハロゲン化物との反応においてゲルミル置換生成物 を与える代表的な機構として次の三つが考えられる。

4 中心機構

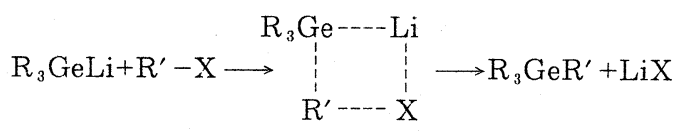

4 中心機構- $\mathrm{S}_{\mathrm{N}} 2$

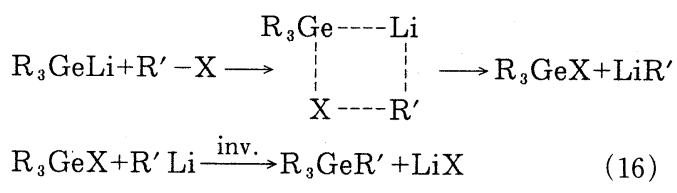

電子移動

$\mathrm{R}_{3} \mathrm{GeLi}+\mathrm{R}^{\prime} \mathrm{X} \longrightarrow\left[\mathrm{R}_{3} \mathrm{GeLi}^{+} \mathrm{R}^{\prime} \mathrm{X}^{-}\right]_{\text {cage }}$

$$
\begin{aligned}
& \longrightarrow\left[\mathrm{R}_{3} \mathrm{Ge} \cdot \mathrm{Li}^{+} \mathrm{R}^{\prime} \cdot \mathrm{X}^{-}\right]_{\text {cage }} \\
& \longrightarrow \mathrm{R}_{3} \mathrm{GeR}^{\prime}+\mathrm{LiX}
\end{aligned}
$$

電子移動反応は, 電子移動に伴なうイオンラジカルの生 成とそれに続くラジカル反応まで意味する。

一体どの反応機構で進むのかを判断する方法としてゲ ルマニウムや炭素中心の立体化学的研究がある。光学活 性なエチル，1-ナフチルフェニルゲルミルリチウム $(1-\mathrm{NpPhEtGe}$ Li $)$ と二，三の有機ハロゲン化物との反応 が Eaborn らによって研究されている。ゲルマニウム上 の立体化学は, 塩化アルキルと臭化アルキルとの反応で は立体配置保持で進むのに対し，ヨウ化アルキルや臭化 ベンジルでは反転で進む。この立体化学の結果は単純な 塩化アルキルや臭化アルキルとの反応は 4 中心機構(式 15)で, 単純なヨウ化アルキルや臭化ベンジルとの反応 は 4 中心機構- $\mathrm{S}_{\mathrm{N}} 2$ (式 16)で進むことを意味する ${ }^{31}$ 。

有機ハロゲン化物の炭素上の立体化学的研究も行われ ている。トリメチルゲルミル陰イオンとハロゲン化シク ロヘキサン誘導体との反応では, シクロヘキサン誘導体 のシス体, トランス体に関わらずゲルミル置換シクロへ キサン誘導体をシス体／トランス体 $=2.3 \sim 4.0$ で生成 する ${ }^{32 \sim 34)}$ 。<smiles>[R]C1CCC(C)CC1</smiles>
または<smiles>[X]C1CCC([R])CC1</smiles><smiles>[R]C1CCC(C(C)C)CC1</smiles><smiles>[R]C1CCC(C(C)(C)C)CC1</smiles>

$\sim 70$

$\sim 30 \quad(\mathrm{R}=\mathrm{Me}, \mathrm{X}=\mathrm{Br}, \mathrm{M}=\mathrm{Li})$

$\sim 80$

$\sim 20\left(\mathrm{R}={ }^{t} \mathrm{Bu}, \mathrm{X}=\mathrm{Br}, \mathrm{M}=\mathrm{Li}, \mathrm{Na}, \mathrm{K}\right)$

反応(式 18)により得られる立体化学の結果は, 置換シ クロヘキシルラジカルからの反応結果と一致する。生成 物の異性体比は生成物の安定性より置換シクロへキシル ラジカルの立体配座により説明できる。

また6-ブロモ-1-へキセンとトリメチルゲルミル陰イ オンとの反応でも中間体としての炭素ラジカルの存在が 指摘されている

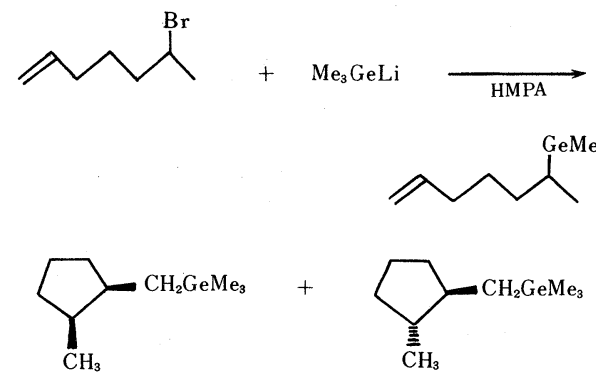


反応式(19)はラジカルクロック(ラジカルの異性化寿命) の手法である。得られた置換シクロペンタンの異性体比 （シス体/トランス体 $=2.7$ ) はフリーな状態にあるラジ カルの環化反応の結果と一致する ${ }^{35)}$ 。

光学活性なゲルマニウム金属の立体化学的研究から得 られた反応機構の結果と有機ハロゲン化物の立場から得 られた反応機構の結果は必ずしも矛盾しない。なぜなら HMPA 溶媒中に扔けるトリメチルゲルミル陰イオンは 非常に一電子移動能力が強いことが知られているからで ある。HMPA 溶媒中でのトリメチルゲルミル陰イオン
と有機ハロゲン化物の反応では，塩素<臭素<ヨウ素の 順に，また一級ハロゲンく二級ハロゲンの順に電子移動 反応が顕著になる ${ }^{10)}$ 。このことは，この順に置換生成物 が減少し，と同時に還元生成物が増大する結果となって あらわれる。

トリアルキルゲルマニウム金属と芳香族ハロゲン化物 との反応生成物もゲルマニウム金属からハロゲン化物へ の電子移動とその結果生成するラジカルの反応によるも のとして説明できる ${ }^{36,37) 。}$
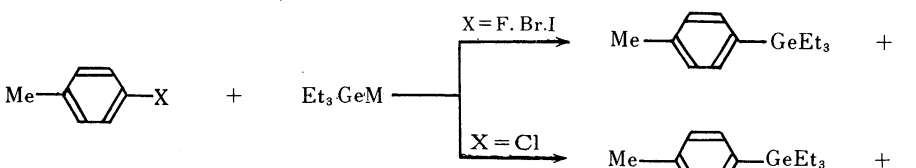<smiles>[Mg]c1ccccc1</smiles>
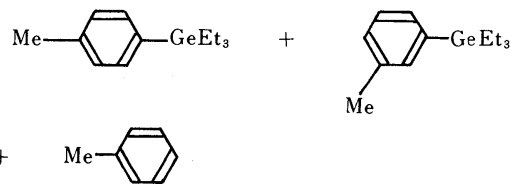

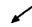

ハロゲン化置換ベンゼンを用いることにより，塩化物で は電子移動反応とベンザイン機構が競争する。塩化ア リールは一電子還元を受けると同時に塩素に関してオル 卜位の水素が酸性で,金属化が起こるためと理解される。 芳香環上のゲルミル基やスタンニル基, あるいは水素 のように通常脱離基として不活性なものまで置換され $3^{38)}$ 。

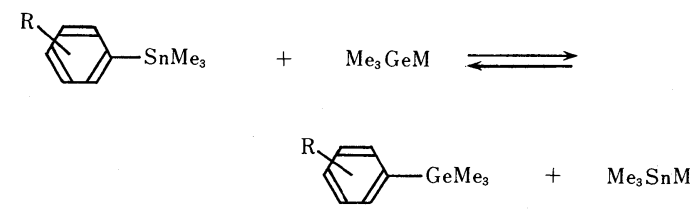

反応(式 22) は可逆的に進む。その反応機構は $t$-ブチル アミン, $t$-ブタノールを炭素陰イオン(カルバニオン) の, ジシクロヘキシルホスフィンを炭素ラジカルの捕捉 剂 39 として用いることにより, 反応(式 22)の大部分は 電子移動で進むことが明らかにされている。

芳香族炭化水素化合物との反応ではアントラセンやピ レンなどと反応し, 還元生成物のジヒドロ体とゲルミル 付加体を生じる ${ }^{10)}$ 。

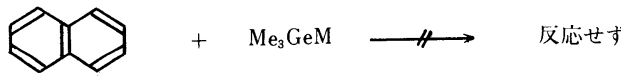

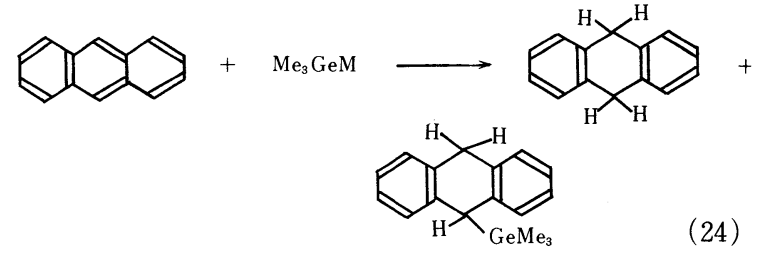

この時，中間のラジカル陰イオンが ESR で観測できる。 しかし, ベンゼンやナフタレンとは反応しない。一方, シリル金属はベンゼンやナフタレンと反応する ${ }^{40)}$ 。 ゲルマニウム金属によるアセチレンへの付加反応は銅 （Ｉ）イオンを共存させることにより位置特異的に進行 し，立体的に不利なビニルゲルマンが生成する ${ }^{41}$ 。<smiles>[R16][R4]#C[R]</smiles>
(R=Et, Ph; $\mathrm{R}^{\prime}={ }^{n} \mathrm{C}_{10} \mathrm{H}_{21}, \quad \mathrm{PhCH}_{2} \mathrm{OCH}_{2} \mathrm{CH}_{2}, \mathrm{Ph}, \mathrm{CH}_{2}=\mathrm{CMe}$ )

ゲルマニウム金属はカルボニル化合物と反応して二種 類のアルコールを生成する ${ }^{6.42,43)}$ 。

$\mathrm{Me}_{3} \mathrm{GeLi}+\mathrm{R}^{1} \mathrm{CR}^{2} \rightarrow \mathrm{R}^{1} \mathrm{R}^{2} \mathrm{CHOH}+\mathrm{R}^{1} \mathrm{R}^{2}\left(\mathrm{Me}_{3} \mathrm{Ge}\right) \mathrm{COH}$ $\left(\mathrm{R}^{1}, \mathrm{R}^{2}=\mathrm{Me}, \mathrm{Ph}\right)$ 
用いる溶媒の種類やカルボニル化合物の種類などにより 二種類のアルコールの生成量は異なる。アセトンとの反 応では $\alpha$-ヒドロキシゲルマンが主生成物となるのに対 し,ベンゾフェノンではカルビノールが主生成物となる。

トリフェニルゲルミルリチウムを塩化ベンゾイルと低 温で反応させると着色化合物のゲルミルケトンが生成す る。と同時にカルビノールも生成する ${ }^{44)}$ 。

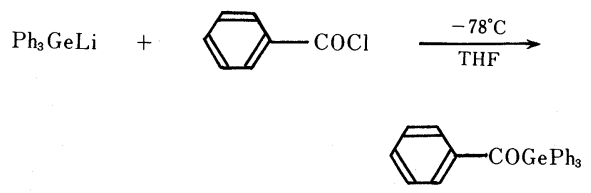

この反応は他のゲルミルケトンの合成には適用できな

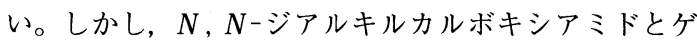
ルマニウム金属の反応は, 種々のゲルミルケトンが合成 でき応用範囲が広い ${ }^{45)}$ 。

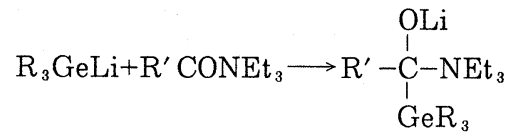

$$
\begin{aligned}
& \stackrel{\mathrm{H}_{2} \mathrm{O}}{\longrightarrow} \mathrm{R}^{\prime} \mathrm{COGeR}_{3}+\mathrm{Et}_{2} \mathrm{NH}
\end{aligned}
$$

$$
\text { ( } \mathrm{R}, \mathrm{R}^{\prime}=\text { アルキル基) }
$$

$\mathrm{THF}$ 中で調製したフェニル置換ゲルミル陰イオンを 光照射するとジゲルマンが定量的に生成する ${ }^{16)}$ 。

$$
2 \mathrm{Ph}_{\mathrm{n}} \mathrm{Me}_{3-\mathrm{n}} \mathrm{Ge}^{-\stackrel{\mathrm{h} \nu}{\longrightarrow}}\left(\mathrm{Ph}_{\mathrm{n}} \mathrm{Me}_{3-\mathrm{n}} \mathrm{Ge}\right)_{2}
$$

反応 (式 29)について詳細に研究され, ゲルミル陰イオン が光照射により励起一重項になる。励起一重項ゲルミル 陰イオンは系間交差により励起三重項を経た後, 一電子 を放出してゲルミルラジカルが生成する。ゲルミルラジ カルの二量化によりジゲルマンが生成する。

ゲルマニウム金属の関与する光反応の研究例は少な い。

\section{5. おわりに}

以上, ゲルマニウム除イオンの合成法, 構造, 反応に 関する最近の報告および著者らの結果をまとめて記し た。本総説でもわかるようにトリアルキル置換ゲルマニ ウム陰イオンに関する研究ははこれからの分野であり, これからの研究のきっかけになれば望外の喜びである。

(平成 2 年 11 月 8 日受理)

\section{文献}

1）例えばD.A. Armitage, “Comprehensive Organometallic Chemistry,” ed by G. Wilkinson, F.G.A. Stone, E.W. Abel, Pergamon Press (1982), Vol.2, Chapt. 9, pp.99-104

2) 桜井英樹, 化学の領域, 30,67 (1976)

3) 藤田, 檜山, 有合化, 42, 293 (1984)

4) D.D. Davis, C.E. Gray, Organomet. Chem. Rev., A, 6, 283 (1970)

5) M. Lesbre, P. Mazerolles, J. Satgé, “The organic compounds of germanium," Interscience Publishers, New York (1971), pp.646-688

6) P. Rivière, M. R-Baudet, J. Satgé, “Comprehensive Organometallic Chemistry," ed by G. Wilkinson, F.G.A. Stone, E.W. Abel, Pergamon Press (1982), Vol.2, Chapt.10, pp. 468-473

7) N.S. Vyazankin, G.A. Razuvaev, E.N. Gladyshev, S.P. Korneva, J. Organomet. Chem . , 7, 353 (1967)

8) E.J. Bulten, J.G. Noltes, Tetrahedron Lett., 1966, 4389

9) E.J. Bulten, J.G. Noltes, J. Organomet. Chem., 29, 397 (1971)

10) 釘田強志; 学習院大学博士学位論文 (1987)

11) W. Kitching, H. Olszowy, J. Waugh, J. Org. Chem., 43, 898 (1978)

12) K. Mochida, N. Matsushige, M. Hamashima, Bull . Chem. Soc.Jpn., 58, 1443 (1985)

13) A. Castel, P. Riviere, J. Satgé, Y-H. Ko, J. Organomet. Chem ., 342, C 1 (1988); Idem ., ibid., Organometallics , 9, 205 (1990)

14) K. Mochida, M. Manishi, Chem. Lett., 1984, 1077

15) K. Mochida, T. Kugita, Y. Nakadaira, Polyhedron, 9, 2263 (1990)

16) K. Mochida, M. Wakasa, Y. Sakaguchi, H. Hayashi, J. Am. Chem. Soc., 109, 7942 (1987)

17) R. Waack, M.A. Doran, ibid., 85, 1651 (1963)

18) G. Frankel, S. Dayagi, S. Kobayashi, J. Phys. Chem., 72, 953 (1968)

19) R.H. Cox , E.G. Janzen, W.B. Harrison, J. Magn. Resonance, 4, 274 (1971)

20) G.A. Olah, R.J. Hunadi, J. Am . Chem. Soc ., 102, 6989 (1980)

21) E. Buncel, T.K. Venkatachalam, B. Eliasson, U. Edlund, ibid., 107, 303 (1985)

22) U. Edlund, T. Lejon, P. Pyykko, T.K. Venkatachalam, E. Buncel, ibid., 109, 5982 (1987)

23) 若狭雅信; 学習院大学博士学位論文 (1988)

24) T. Kugita, K. Mochida, K. Tohji, Y. Udagawa, Chem. Lett., 1989, 501

25) D.E. Sayers, E. A. Stern, F.W. Lytle, Phys. Rev. Lett. , 27, 1204 (1971)

26) K. Mochida, A. Fujii, N. Tsuchiya, K. Tohji, Y. 
Udagawa, Organometallics, 6, 1811 (1987)

27) V.I. Korsunsky, M.B. Taraban, T.V. Leshina, O.I. Margorskaya, N. S. Vyazankin, J. Organomet. Chem., 215, 179 (1981)

28) K. Mochida, T. Kugita, Main Group Metal Chem., 11,215 (1988)

29) P. Kebarle, S. Chowdhury, Chem. Rev., 87, 513 (1987)

30) J.K. Kochi, “Organometallic Mechanism and Catalysis,” Academic Press (1978)

31) C. Eabron, R.E.E. Hill, P. Simpson, J. Orga nomet. Chem., 37, 275 (1972)

32) W. Kitching, H. Olszowy, K. Harvey, J. Org. Chem., 46, 2433 (1981);Idem., ibid., 47, 1893 (1982)

33) W. Kitching, H. Olszowy, J. Waugh, D. Doddrel, J. Org. Chem., 43, 898 (1978)

34) K. Mochida, T. Kugita, Bull. Chem. Soc .Jpn ., 61, 3727 (1988)

35) A.L.J. Beckwith, I. Blair, G. Phillipou, J. Am . Chem. Soc . , 96, 1613 (1974) and references therein

36) K. Mochida, N. Matsushige, J. Organomet. Chem.,
229, 11 (1982)

37) J-P. Ouintard, S. Hauvette-Frey, M. Pereyre, C. Couret, J. Satgé, C.R. Acad, Sci, Paris, 287, 247 (1978)

38）持田，釘田，日化誌，1985，334

39) G.F. Smith, H.G. Kuivila, R. Simon, L. Sultan, J. Am. Chem. Soc., 103, 833 (1981)

40) H. Sakurai, A. Okada, M. Kira, K. Yonezawa, Tetrahedron Lett., 1971, 1511

41) H. Oda, Y. Morizawa, K. Oshima, H. Nozaki, Tetrahedron Lett., 25, 3217 (1984)

42）持田, 南場, 未表発結果

43) I.S. Biltueva, D.A. Bravo-Zhivotovskii, I.D. Kalikhman, V.Y. Vitkovskii, S.G. Shevchenko, N.S. Vyazankin, M.G. Voronkov, J. Organomet. Chem., 368, 163 (1989)

44) D.A. Nicholson, A.L. Allred, Inorg. Chem., 4, 1747 (1965)

45) D.A. Bravo-Zhivotovskii, S.D. Pigrev, I.D. Kalikhman, O.A. Vyazankin, N.S. Vyazankin, J. Organomet. Chem., 248, 51 (1983)

\section{本誌広告料金}

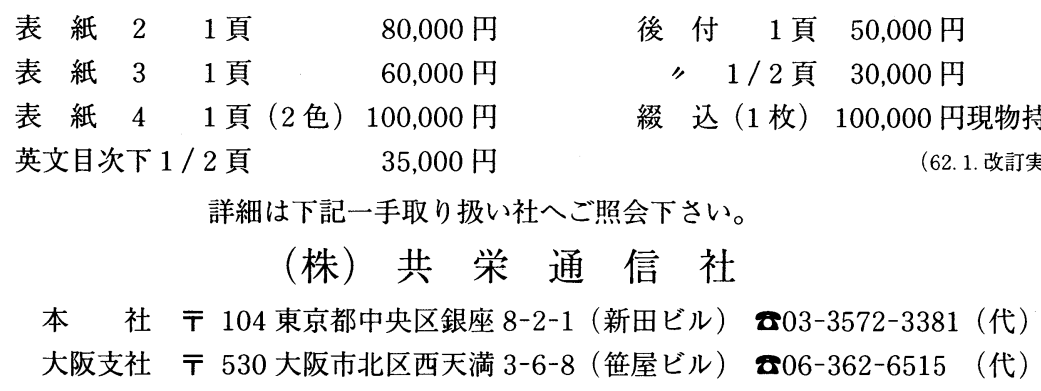

